\title{
URBAN AND RURAL POPULATION BIRTH-RATE RESEARCH IN THE NORTH CAUCASIAN FEDERAL DISTRICT
}

\author{
(C) Nodar G. Caberty, Alexander V. Dzhioev
}

\author{
Laboratory of Applied Sociology and Conflictology, \\ Vladikavkaz Scientific Center of Russian Academy of Sciences, \\ Vladikavkaz, Republic of North Ossetia-Alania, Russian Federation \\ kaberti-n@mail.ru, dzhioevsasha@gmail.com
}

The article is devoted to the study of regional characteristics of the birth-rate among urban and rural population in the regions of the North Caucasian Federal District. In the works of Russian and foreign authors, the level of urbanization is recognized as an important factor influencing the reproductive behavior of the population. The purpose of the study is to determine characteristics of the level and change in the intensity of the birth-rate in the regions of the North Caucasian Federal District in the context of city-village. The analysis covered a fairly long period $(1990-2018)$. It is revealed that despite the fact that the demographic crisis in the North Caucasus is relatively mild, it negatively affected all processes of natural movement, including the birth-rate. A comparative analysis of overall and partial birth-rate coefficients in urban and rural areas of all regions of the North Caucasian Federal District was carried out and it is found that over the entire analyzed period there was a convergence of the birth-rate indicators of cities and villages. The difference reduced mainly due to the decrease of the rural birth-rate. Regional features of such convergence in individual subjects of the North Caucasian Federal District are revealed. Based on the results of a survey of the population on the desired and expected number of children in the family, in micro-census of 2015, it is concluded that the regional and rural-urban differentiation of the intensity of the birth-rate in the North Caucasus will continue in the future.

Key words: birth-rate, birth-rate indicators, regions of the North Caucasian Federal District, urban population, rural population, age coefficients.

\section{[Н.Г. Каберты, А.В. Джиоев Исследование рождаемости городского и сельского населения Се- веро-Кавказского федерального округа]}

Статья посвящена исследованию региональных особенностей рождаемости среди городского и сельского населения в регионах Северо-Кавказского федерального округа (СКФО). В работах российских и зарубежных авторов уровень урбанизации признан важным фактором, влияющим на репродуктивное поведение населения. Цель исследования заключается в определении особенностей уровня и изменения интенсивности рождаемости в регионах СКФО в разрезе город-село. Анализ охватил довольно длительный период (1990 - 2018 гг.). Выявлено, что несмотря на то, что на Северном Кавказе демографический кризис проходит относительно мягко, он отрицательно отразился на всех процессах естественного движения, в том числе и на уровне рождаемости. Проведен компаративный анализ общих и частных коэффициентов рождаемости в городских и сельских местностях всех регионов СКФО и установлено, что за весь анализируемый период шло сближение показателей рождаемости города и села. Разница сокращалась, главным образом, за счет уменьшения сельской рождаемости. Выявлены региональные особенности такого сближения по отдельным субъектам СКФО. Опираясь на результаты опроса населения о желаемом и ожидаемом числе детей в семье, в ходе микропереписи населения 2015 года, сделан вывод, что региональная и сельско-городская дифференциация интенсивности рождаемости на Северном Кавказе сохранится и в будущем.

Ключевые слова: рождаемость, показатели рождаемости, регионы Северо-Кавказского федерального округа, городское население, сельское население, возрастные коэффициенты.

Nodar G. Caberty - Ph.D. in Economics, Associate Professor, Senior Research Fellow, Laboratory of Applied Sociology and Conflictology, Vladikavkaz Scientific Center of Russian Academy of Sciences, Vladikavkaz, Republic of North Ossetia-Alania, Russian Federation.

Alexander V. Dzhioev - Junior Research Fellow, Laboratory of Applied Sociology and Conflictology, Vladikavkaz Scientific Center, Russian Academy of Sciences, Vladikavkaz, Republic of North Ossetia-Alania, Russian Federation. 
Каберты Нодар Гаврилович - кандидат экономических наук, доцент, старший научный сотрудник, Лаборатория прикладной социологии и конфликтологии, Владикавказский научный центр Российской академии наук, Владикавказ, Республика Северная Осетия - Алания, Российская Федерация.

Джиоев Александр Валерьевич - младший научный сотрудник, Лаборатория прикладной социологии и конфрликтологии, Владикавказский научный центр Российской академии наук, Владикавказ, Республика Северная Осетия - Алания, Российская Федерация.

Improving the demographic situation is one of the strategic objectives of modern Russia. The most important aspect of the development and implementation of effective policies in this area... "is a comprehensive analysis of population reproduction, which allows us to determine both positive and negative trends in demographic development, their determinants, prospects, as well as their possible consequences" [7, p.157].

Among the huge number of factors influencing the current and expected intensity of the birth-rate, the following factors are distinguished most frequently: the standard of living of the population; satisfaction with the financial situation of the family; housing conditions; the crisis of the traditional family; education development; social security development; provision of children's institutions; the employment rate of women; the nature and working conditions of women; development of the health system; reproductive health of the population (especially women), etc.

The nature and intensity of these and other factors largely depend on the structure of the population and the so-called demographic factors. These are the sexual age, family, marriage, national, cultural and educational composition of the population. Researchers agree that these factors are mutually conditioned and systemically interconnected, therefore establishing the nature and intensity of influence of each of them on the birth-rate is a difficult task to solve. The conditions forming these factors, as well as their environment, are differentiated across countries and regions.

The level of population urbanization, that is a ratio of urban to rural population, is considered an important factor in demographic changes, including reproductive behavior features. Relevant studies show that, under equal conditions, the birth-rate in cities is lower than in rural areas. Therefore, the birth-rate is higher in those countries and regions where the percentage of rural population is higher. Most often, this situation is due to the fact that in cities women marry later, urban women are usually limited to one child in the family, while rural women limit the birth-rate more often after the birth of the second child. Therefore, urbanization has always been seen as a negative factor influencing on the level of the birth-rate. To eliminate this factor of reproductive behavior of women in Russian cities, until the beginning of the 60 s of the last century, some measures were used to prevent migration of the population from rural to urban areas. As a result of such restrictive measures, a high proportion of young people and therefore high reproductive potential remained in rural areas of the Soviet Union.

However, the birth-rate discrepancy according to the types of settlement is neither everywhere nor always the same; it is constantly changing, and usually towards rapprochement. Back in 1960, the overall birth-rate coefficient in rural areas of Soviet Russia was higher than the same indicator among the urban population by 6.1 point. As a result of constant rapprochement, this discrepancy had decreased to 2.8 point by 1990 , that is $12.7 \%$ in cities and $15.5 \%$ in rural areas [2, table 2.1]. The excess of the birth-rate coefficient among the rural population over the same indicator in the urban population had been also recorded in the regions of the North Caucasian Federal District within its current borders by 1990. The largest difference was noted in Chechen-Ingush Republic, that was 9.6 point, and the lowest, only 0.5 point, was in North Ossetia.

Since the beginning of the 1990s, the birth-rate has decreased among both rural and urban populations of Russia, including the regions of the North Caucasus, with the exception of urban population of Chechnya. At the same time, the decline of the birth-rate indica- 
tor was faster in rural areas. As a result of this differentiated dynamics, the overall birthrate coefficient among urban and rural population had gradually equalized. The indicator decreased among the rural population of Dagestan and Kabardino-Balkaria especially quickly. The decrease in both cases during the period under the analysis was more than 12 points.

Despite the unfavorable dynamics, in rural areas of Dagestan, Ingushetia and Kabardino-Balkaria, the overall birth-rate coefficient remained higher compared to other regions. According to the latest statistics, in a number of regions of the North Caucasian Federal District (Chechnya, North Ossetia, Karachay-Cherkessia and in the Stavropol Territory), more children per thousand people are born in cities than in rural areas.

The differentiated levels, nature and pace of change of the birth-rate indicators in cities and rural areas are, in our view, caused by the following factors:

1. Changes in the age structure of the population, especially the proportion of young women with high reproductive potential;

2. The degree of satisfaction with socio-economic services.

During the whole period under the analysis, the faster decrease in the overall birthrate coefficient in rural areas (and its corresponding alignment in the city-village context) is explained precisely by the deterioration of the age structure of the rural population, that is the result of an intensive outflow of young people from rural to urban areas.

Numerous studies have shown that the deterioration of the age structure of the population, especially the decline in the number of young women, is the most significant and negatively affecting the birth-rate factor. However, according to the relevant observations, the gradual spread of urban lifestyle in rural areas and, in particular, in the field of reproductive behavior of the population plays an important role in reducing the extent and intensity of the birth-rate [1, p.100].

It is important to note that for the study of the requisites of such convergence and the determination of the influence of the above factors on the change of the birth-rate intensity, the overall coefficients are of little use. Their main disadvantage, the absence of taking into account the heterogeneity of the population structure, is usually eliminated using partial, for example, age coefficients. Among them, the so-called special birth-rate coefficient, reflecting the intensity of childbirth among women of fertile age (15-49 years), is quite informative. When calculating it, the age contingent of women is not taken into account, which practically does not affect the number of births and, thereby, the intensity of the birth-rate is more adequately characterized. Our calculations showed that over the last almost 30-year period, the special birth-rate coefficient decreased at different rates both in cities and in rural areas of Russia and in the regions of the North Caucasus (Table 1).

Table 1. The level and dynamics of the special birth-rate coefficient in the regions of the North Caucasian Federal District in the context of the city-village (per 1000 women of fertile age) $[3 ; 4 ; 5 ; 11]$

\begin{tabular}{|l|l|l|l|l|l|}
\hline Regions & 1990 & 2005 & 2010 & 2015 & 2018 \\
\hline Russian Federation: city & 49,3 & 34,7 & 44,5 & 53,2 & 44,7 \\
\hline village & 76,4 & 43,1 & 58,1 & 59,1 & 50,8 \\
\hline Dagestan: city & 89,8 & 41,5 & 48,6 & 50,2 & 43,8 \\
\hline village & 125,5 & 61,1 & 72,3 & 79,0 & 70,7 \\
\hline Ingushetia*: city & 73,6 & 47,9 & 85,7 & 58,6 & 48,8 \\
\hline village & 119,3 & 44,4 & 89,0 & 65,6 & 65,4 \\
\hline Kabardino-Balkaria: city & 65,4 & 28,7 & 46,2 & 54,1 & 47,6 \\
\hline
\end{tabular}

* In 1990, the Chechen-Ingush Autonomous Soviet Socialist Republic 


\begin{tabular}{|l|l|l|l|l|l|}
\hline village & 108,0 & 41,4 & 57,3 & 57,4 & 52,0 \\
\hline Karachay-Cherkessia: city & 58,2 & 38,3 & 39,9 & 45,9 & 43,0 \\
\hline village & 84,9 & 45,0 & 51,3 & 48,8 & 42,1 \\
\hline $\begin{array}{l}\text { Republic of North Ossetia- } \\
\text { Alania: city }\end{array}$ & 68,1 & 42,9 & 53,4 & 60,5 & 57,4 \\
\hline village & 77,0 & 38,8 & 55,9 & 54,7 & 48,7 \\
\hline Chechnya ${ }^{*}$ city & 73,6 & 119,9 & 110,4 & 95,4 & 87,7 \\
\hline village & 119,3 & 70,7 & 112,4 & 87,1 & 77,7 \\
\hline Stavropol Territory: city & 51,9 & 34,1 & 41,1 & 50,9 & 44,1 \\
\hline village & 78,5 & 39,6 & 49,4 & 53,4 & 46,1 \\
\hline
\end{tabular}

As shown in table 1, the decline of the coefficient is in the first half of the analyzed period, when in Russia as a whole and in the regions of the North Caucasus (excluding the urban population of Chechnya), in particular, in 2005 the coefficient fell to its historical minimum. In the future, until 2015, both in cities and in rural areas there was a significant increase of the indicator. In recent years, the coefficient is declining again in the country and in the analyzed regions.

Based on the comparative analysis of overall and special birth-rate coefficients, it can be concluded that the deterioration of the birth-rate parameters in Russia and in the North Caucasus occurs not only as a result of the deterioration in the age structure of the entire population, but also due to the change for the worse in the reproductive attitudes of women of the fertile age. To a lesser extent, the birth-rate still depends on the characteristics of the age composition of women of the fertile age. Naturally, within the fertile age, the degree of influence of certain factors on the formation of reproductive attitudes is highly differentiated by age groups of women. Among young people, acute socio-economic problems usually come to the fore. Measures of regulating the processes of the population reproduction in Soviet Russia were aimed to solve these problems.

In 1990, in Russia and in the regions of the North Caucasus, both among women of the fertile age and in all age groups within it, the intensity of the birth-rate in rural areas was significantly higher compared to the urban population (table 2).

Table 2. The age birth-rate coefficients in 1990 in the context of the village-city (per 1000 women of the corresponding age) [9]

\begin{tabular}{|l|l|l|l|l|l|l|l|}
\hline \multirow{2}{*}{ Regions } & \multicolumn{7}{|l|}{ Age of the mother at the birth of the child, years old } \\
\cline { 2 - 8 } & $15-19$ & $20-24$ & $25-29$ & $30-34$ & $35-39$ & $40-44$ & $45-49$ \\
\hline Russian Federation: city & 47,7 & 141,2 & 85,9 & 44,1 & 17,0 & 3,4 & 0,1 \\
\hline village & 82,0 & 207,1 & 116,2 & 61,9 & 28,3 & 7,6 & 0,3 \\
\hline Dagestan: city & 31,9 & 192,7 & 158,7 & 89,0 & 34,7 & 8,8 & 0,4 \\
\hline village & 38,7 & 252,2 & 207,6 & 126,4 & 56,3 & 20,0 & 2,0 \\
\hline Kabardino-Balkaria: city & 41,3 & 156,3 & 116,2 & 63,4 & 27,7 & 4,1 & 0,4 \\
\hline village & 83,2 & 260,2 & 149,6 & 82,6 & 33,4 & 6,2 & 0,1 \\
\hline $\begin{array}{l}\text { Karachay-Cherkessia: } \\
\text { city }\end{array}$ & 39,5 & 142,3 & 102,2 & 59,1 & 26,5 & 5,0 & 0,0 \\
\hline village & 49,1 & 182,4 & 137,2 & 84,5 & 38,8 & 8,4 & 0,2 \\
\hline $\begin{array}{l}\text { Republic of North } \\
\text { Ossetia-Alania: city }\end{array}$ & 28,2 & 152,5 & 136,3 & 81,9 & 34,3 & 8,0 & 0,2 \\
\hline village & 39,1 & 161,3 & 126,5 & 84,9 & 39,0 & 8,2 & 0,5 \\
\hline Stavropol Territory: city & 47,6 & 145,6 & 90,0 & 45,0 & 17,0 & 3,4 & 0,2 \\
\hline village & 94,6 & 217,9 & 117,1 & 57,3 & 22,8 & 5,5 & 0,2 \\
\hline $\begin{array}{l}\text { Checheno-Ingushetia: } \\
\text { city }\end{array}$ & 28,0 & 132,4 & 129,3 & 86,4 & 45,7 & 9,6 & 0,3 \\
\hline village & & & & & & & 25,5 \\
\hline
\end{tabular}


Despite the fact that by that time the demographic crisis had been already approaching in Russia, among young women (20-29 years old), the birth-rate was still quite high, especially in rural areas. In the North Caucasus, the decline of the birth-rate intensity had not been felt practically by that time. In both urban and rural areas of the North Caucasus, all age birth-rate coefficients were higher than those of the federal level. In general, in all regions of the North Caucasus, a large discrepancy of the age birth-rate coefficients is recorded in favor of rural residents, especially among young women. In this regard, Kabardino-Balkaria, Dagestan and Checheno-Ingushetia were especially distinguished. For example, the birth-rate among women aged 20-24 years in rural areas of KabardinoBalkaria was two and a half times higher than that of the urban population. The age coefficients in the context of the city-village were relatively little different in the Stavropol Territory and in North Ossetia. The intensity of the birth-rate in the age group of women (25-29 years old) in the cities of North Ossetia was even higher than the corresponding indicator in rural areas.

According to the demographic statistics of modern Russia, since the beginning of the 1990s, the birth-rate had been intensively declining in all regions of the North Caucasus as well as in the whole country. This negative process was particularly rapid among young rural women. As a result of such differentiated dynamics in the North Caucasus, the age birth-rate coefficients among urban and rural populations had converged. By 2005, a noticeable excess of the birth-rate coefficients of young women in rural areas remained in Dagestan, in Kabardino-Balkaria and in Karachay-Cherkessia (table 3). In other regions of the North Caucasus, the reproductive superiority of the rural population had almost disappeared.

Table 3. The age birth-rate coefficients of urban and rural population in the North Caucasian Federal District regions in 2005 (per 1000 women of the corresponding age) [3, Table 4.4.]

\begin{tabular}{|l|l|l|l|l|l|l|l|}
\hline \multirow{2}{*}{ Regions } & \multicolumn{7}{|l|}{ Age of the mother at the birth of the child, years old } \\
\cline { 2 - 8 } & $15-19$ & $20-24$ & $25-29$ & $30-34$ & $35-39$ & $40-44$ & $45-49$ \\
\hline Russian Federation: city & 23,0 & 78,8 & 75,5 & 44,9 & 17,4 & 2,8 & 0,1 \\
\hline village & 39,0 & 120,7 & 85,6 & 46,5 & 18,7 & 3,6 & 0,2 \\
\hline Dagestan: city & 14,1 & 78,3 & 83,4 & 53,9 & 26,8 & 6,0 & 0,4 \\
\hline village & 23,0 & 147,2 & 123,6 & 74 & 34,1 & 8,0 & 0,8 \\
\hline Ingushetia: city & 11,3 & 78,5 & 97,4 & 93,8 & 65,2 & 20,6 & 2,1 \\
\hline village & 8,6 & 71,7 & 95,9 & 83,2 & 64 & 23,0 & 3,7 \\
\hline Kabardino-Balkaria: city & 17,1 & 63,2 & 65,5 & 42,5 & 19,5 & 3,8 & 0,4 \\
\hline village & 23,7 & 106,0 & 85,3 & 45,7 & 17,1 & 3,9 & 0,2 \\
\hline $\begin{array}{l}\text { Karachay-Cherkessia: } \\
\text { city }\end{array}$ & 20,0 & 74,4 & 79,3 & 49,5 & 26,9 & 4,9 & 0,7 \\
\hline village & 22,9 & 83,1 & 97,6 & 61 & 27,1 & 6,4 & 1,0 \\
\hline $\begin{array}{l}\text { Republic of North } \\
\text { Ossetia-Alania: city }\end{array}$ & 16,7 & 84,5 & 99,0 & 64,9 & 30,2 & 7,4 & 0,4 \\
\hline village & 21,0 & 81,9 & 78,0 & 46,6 & 21,4 & 6 & 1,1 \\
\hline Chechnya: city & 85,3 & 233,7 & 209,2 & 150,9 & 94,7 & 29,5 & 3,5 \\
\hline village & 54,6 & 140,4 & 122,6 & 86,0 & 48,0 & 15,8 & 1,2 \\
\hline Stavropol Territory: city & 20,8 & 72,5 & 79,0 & 41,7 & 14,6 & 2,5 & 0,2 \\
\hline village & 35,6 & 103,3 & 77,3 & 38,2 & 14,5 & 2,5 & 0,1 \\
\hline
\end{tabular}

The coefficients in these regions equalized or on the contrary in most age groups of women they were significantly higher in cities than in rural areas. North Ossetia and Chechnya are the examples. In these republics, the intensity of childbearing in all age groups in cities is significantly higher than analogic indicators among the rural population. 
After the long and deep demographic crisis in most regions of Russia, over the past decade and a half, there has been some improvement of the population reproduction indicators. This positive process also affected the age birth-rate coefficients in the North Caucasus regions (table 4).

Table 4. The age birth-rate coefficients of urban and rural population in the North Caucasian Federal District regions in 2018 (per 1000 women of the corresponding age) [6, Table 4.2.]

\begin{tabular}{|l|l|l|l|l|l|l|l|}
\hline \multirow{2}{*}{ Regions } & \multicolumn{7}{|l|}{ Age of the mother at the birth of the child, years old } \\
\cline { 2 - 8 } & $15-19$ & $20-24$ & $25-29$ & $30-34$ & $35-39$ & $40-44$ & $45-49$ \\
\hline Russian Federation - city & 12,5 & 70,2 & 90,8 & 75,9 & 40,1 & 9,1 & 0,6 \\
\hline village & 25,9 & 101,2 & 120,3 & 76,9 & 38,1 & 8,1 & 0,3 \\
\hline Dagestan: city & 19,2 & 96,8 & 66,8 & 55,2 & 31,9 & 8,3 & 0,6 \\
\hline village & 42,2 & 155,8 & 132,2 & 83,0 & 41,3 & 8,8 & 0,5 \\
\hline Ingushetia: city & 1,4 & 87,8 & 96,9 & 70,4 & 45,1 & 15,6 & 0,8 \\
\hline village & 3,7 & 112,7 & 120,1 & 90,5 & 59,8 & 19,4 & 0,8 \\
\hline Kabardino-Balkaria: city & 15,2 & 87,4 & 95,5 & 66,3 & 37,3 & 9,7 & 0,5 \\
\hline village & 19,8 & 105,7 & 101,7 & 68,0 & 32,2 & 6,0 & 0,4 \\
\hline Karachay-Cherkessia: city & 9,9 & 72,3 & 89,5 & 71,9 & 36,2 & 7,8 & 1,0 \\
\hline village & 14,9 & 78,7 & 90,4 & 61,1 & 29,4 & 6,7 & 0,6 \\
\hline $\begin{array}{l}\text { Republic of North } \\
\text { Ossetia-Alania: city }\end{array}$ & 11,6 & 83,7 & 125,3 & 98,7 & 53,6 & 14,2 & 1,3 \\
\hline village & 16,0 & 82,5 & 104,1 & 73,7 & 37,6 & 10,7 & 0,5 \\
\hline Chechnya: city & 33,4 & 177,2 & 159,2 & 110,4 & 59,6 & 17,8 & 2,0 \\
\hline village & 35,0 & 159,4 & 139,0 & 98,5 & 48,0 & 12,7 & 1,1 \\
\hline Stavropol Territory: city & 15,6 & 82,5 & 75,7 & 70,1 & 35,2 & 7,7 & 0,5 \\
\hline village & 26,4 & 101,3 & 94,5 & 63,8 & 31,4 & 6,6 & 0,1 \\
\hline
\end{tabular}

Comparison of the data of tables 4 and 5 shows that, firstly, in 2005-2018, the absolute majority of the age birth-rate coefficients in all regions of the North Caucasus increased, and secondly, the interregional differentiation of the birth-rate indicators in both cities and rural areas remained almost unchanged.

In 2018, in only two republics, in Dagestan and Ingushetia, the intensity of the birthrate in all age groups in rural areas exceeded analogic indicators of the urban population. The similar situation was recorded among young women in Kabardino-Balkaria and in the Stavropol Territory, where the intensity of the birth-rate among more older women is higher in cities than in villages. In other regions of the North Caucasian Federal District, in almost all age groups, the intensity of the birth-rate in cities is higher than in rural areas.

The level and trends of the birth-rate indicators, their particular characteristics in urban and rural areas, can be more deeply characterized by the total birth-rate coefficient, which shows how many children are given birth by a woman an average for the entire fertile age, and which is not practically influenced by changes in the age structure of women.

The establishment of a critical level of the indicator is indispensable for analyzing this coefficient. Such a level, in other equal conditions, ensured the simple reproduction of the population; there is a narrowed reproduction of the population below this, and an expanded reproduction of the population above this. The opinion about the critical level varies significantly, but the most common is 2,12 births per woman on average, for the entire childbearing period. Focusing on this level, it can be said that in 1990, expanded reproduction of the population was ensured in the rural areas of Russia as a whole and in all regions of the North Caucasus. Among the urban population, extended reproduction was ensured in Dagestan, Ingushetia, North Ossetia and Chechnya. In the cities of the Stavropol Territory, Karachay-Cherkessia, Kabardino-Balkaria, the total coefficient was much 
less than the critical value, and therefore, even simple reproduction of the population was not provided in these regions. Since the 1990s, in the regions of the North Caucasus, the total birth-rate coefficient has had a steady declining trend among both urban and rural populations (table 5).

Table 5. Level and dynamics of the aggregate birth-rate coefficient in Russia and in the regions of the North Caucasus in the context of the village-city [6;8]

\begin{tabular}{|l|l|l|l|l|l|}
\hline Regions & 1990 г. & $2005 \Gamma$. & 2010 & 2015 & 2018 \\
\hline Dagestan: city & 2,57 & 1,32 & 1,51 & 1,51 & 1,39 \\
\hline village & 3,52 & 2,11 & 2,31 & 2,55 & 2,32 \\
\hline Ingushetia*: city & 2,15 & 1,63 & 2,78 & 1,90 & 1,60 \\
\hline village & 3,35 & 1,52 & 3,15 & 2,02 & 2,04 \\
\hline Kabardino-Balkaria: city & 2,04 & 0,96 & 1,52 & 1,71 & 1,56 \\
\hline village & 3,10 & 1,40 & 1,83 & 1,79 & 1,67 \\
\hline Karachay-Cherkessia: city & 1,89 & 1,34 & 1,31 & 1,48 & 1,45 \\
\hline village & 2,51 & 1,61 & 1,67 & 1,58 & 1,41 \\
\hline $\begin{array}{l}\text { Republic of North Ossetia-Alania: } \\
\text { city }\end{array}$ & 2,20 & 1,52 & 1,82 & 2,00 & 1,94 \\
\hline village & 2,30 & 1,34 & 1,86 & 1,80 & 1,62 \\
\hline Chechnya*: city & 2,15 & 4,05 & 3,44 & 2,96 & 2,82 \\
\hline village & 3,35 & 2,31 & 3,46 & 2,71 & 2,45 \\
\hline Stavropol Territory: city & 1,73 & 1,11 & 1,33 & 1,55 & 1,43 \\
\hline village & 2,64 & 1,38 & 1,63 & 1,81 & 1,63 \\
\hline
\end{tabular}

Despite the negative dynamics of the birth-rate coefficient for the analyzed period in table 5, expanded reproduction of the population was ensured among urban and rural population of Chechnya, among rural population of Dagestan and Ingushetia (since 2010). In other regions, there is a narrowed reproduction of the population. Analysis of table 5 data also shows that throughout the analyzed period (1990-2018) there was a constant convergence of city and village indicators. The difference was reduced mainly by the reduction of the rural birth-rate, although in some cases there was an increase in the total birth-rate coefficient in cities.

The following pattern is well known: the birth-rate among urban residents who has recently moved from rural areas is higher than that among people living in the city for a long time. In rural areas the North Caucasus regions, this process, that is, the spread of urban reproductive behavior, takes place locally without rural-urban migration. This is the result of the spread of urban lifestyle in villages, an increase in the needs of rural residents for socioeconomic services. The decline in satisfaction with these services in general leads to the deterioration in the demographic situation and the decrease in the parameters of demographic targets. Judging by the answers to questions on the desired and expected number of children in the family obtained during the 2015 micro-census in Russia, the regional and rural-urban differentiation in the birth-rate intensity in the North Caucasus will continue in the future.

In addition to other information, the above-mentioned information is confirmed by the ratio of women respondents focused on the birth of no more than two or three and more children (table 6). The interregional analysis of this ratio shows that in Ingushetia, Chechnya and Dagestan, the proportion of women oriented on the abundance of children is several times higher than the same indicator in the whole country and much higher than in other regions of the North Caucasian Federal District. That is true of both urban and rural orientation.

\footnotetext{
* In 1990, the Chechen-Ingush Autonomous Soviet Socialist Republic
} 
Table 6. Desired and expected number of children among women aged 18-44 years in urban and rural areas of the regions of the North Caucasian Federal District [10]

\begin{tabular}{|c|c|c|c|c|c|}
\hline & \multirow{2}{*}{$\begin{array}{l}\text { Total surveyed } \\
\text { women aged 18- } \\
44 \text { years }\end{array}$} & \multicolumn{2}{|c|}{$\begin{array}{l}\text { With the desired number } \\
\text { of children, } \%\end{array}$} & \multicolumn{2}{|c|}{$\begin{array}{l}\text { With the expected num- } \\
\text { ber of children, } \%\end{array}$} \\
\hline & & $0-2$ & $\begin{array}{l}3 \text { and } \\
\text { more }\end{array}$ & $0-2$ & $\begin{array}{l}3 \text { and } \\
\text { more }\end{array}$ \\
\hline $\begin{array}{l}\text { Russian Federation: urban } \\
\text { population }\end{array}$ & 100 & 81,3 & 18,7 & 88,5 & 11,5 \\
\hline rural population & 100 & 72,6 & 27,4 & 79,3 & 20,7 \\
\hline Dagestan: urban population & 100 & 48,9 & 51,1 & 62,8 & 37,2 \\
\hline rural population & 100 & 35,8 & 64,2 & 46,6 & 53,4 \\
\hline Ingushetia: urban population & 100 & 45,3 & 54,7 & 53,8 & 46,2 \\
\hline rural population & 100 & 28,2 & 71,8 & 47,0 & 53,0 \\
\hline $\begin{array}{l}\text { Kabardino-Balkaria: urban } \\
\text { population }\end{array}$ & 100 & 59,2 & 40,8 & 69,7 & 30,3 \\
\hline rural population & 100 & 53,2 & 46,8 & 60,5 & 39,5 \\
\hline $\begin{array}{l}\text { Karachay-Cherkessia: urban } \\
\text { population }\end{array}$ & 100 & 54,7 & 45,3 & 69,5 & 30,5 \\
\hline rural population & 100 & 40,2 & 59,8 & 56,1 & 43,9 \\
\hline $\begin{array}{l}\text { Republic of North } \\
\text { Ossetia-Alania: urban popula- } \\
\text { tion }\end{array}$ & 100 & 62,0 & 38,0 & 73,0 & 27,0 \\
\hline rural population & 100 & 61,1 & 38,9 & 67,1 & 32,9 \\
\hline Chechnya: urban population & 100 & 41,7 & 58,3 & 47,2 & 52,8 \\
\hline rural population & 100 & 31,8 & 68,2 & 38,6 & 61,4 \\
\hline $\begin{array}{l}\text { Stavropol Territory: } \\
\text { population }\end{array}$ & 100 & 76,2 & 23,8 & 87,1 & 12,9 \\
\hline rural population & 100 & 70,2 & 29,8 & 78,3 & 21,7 \\
\hline
\end{tabular}

Analysis of table 6 data shows that in the regions of the North Caucasus, as in Russia as a whole, the proportion of women focused on abundance of children in rural areas is higher than in cities. At the same time, the rural-urban discrepancy in the proportion of wishing and awaiting birth of more than 2 children is very differentiated according to the regions of the North Caucasian Federal District. The highest discrepancy was recorded in Dagestan and in Karachay-Cherkessia, the lowest was recorded in North Ossetia.

It is important to note that in Russia as a whole, as well as in all North Caucasus regions, the proportion of women wishing to have three or more children turned out to be higher than those expecting the birth of such a number of children. The parameters of this discrepancy, together with other data of the analysis of the reproductive behavior of the population, with their characteristics by types of settlement, provide a good basis for the development and implementation of effective regional population policy.

\section{Лumepamypa}

1. Архангельский В.Н. Факторы рождаемости. М.: ТЕИС, 2006. - с. 399

2. Демографический ежегодник России. 2002. Стат. сборник. Росстат. М., 2003. [Электронный ресурc] URL: http://www.gks.ru

3. Демографрический ежегодник России. 2006. Стат. сборник. Росстат. М., 2007. [Электронный ресурc] URL: http://www.gks.ru 
4. Демографический ежегодник России. 2010. Стат. сборник. Росстат. М., 2011. [Электронный ресурc] URL: http://www.gks.ru

5. Демографический ежегодник России. 2015. Стат. сборник. Росстат. М., 2016. [Электронный ресурc] URL: http://www.gks.ru

6. Демографический ежегодник России. 2019. Стат. сборник. Приложения. Росстат. - М., 2020. [Электронный ресурс] URL: http://www.gks.ru

7. Демографический фактор в социально-экономическом развитии региона (на примере Пермской области) / Под. ред. В.А. Ионцева. М.: ТЕИС, 2004. - с. 256

8. Демоскоп. Демографический электронный журнал. Приложения. [Электронный pecypc]. URL:http://demoscope.ru/weekly/pril.php

9. Единая межведомственная информационно-статистическая система (ЕМИСС) https://fedstat.ru/indicator/36727

10. Итоги микропереписи населения РФ 2015 г. Раздел V - рождаемость и репродуктивные планы.

11. [Электронный ресурc]: URL:http://www.gks.ru/free_doc/new_site/population/demo/ micro-perepis/finish/micro-perepis.html

12. Рождаемость, смертность, естественный прирост населения по субъектам РФ за 2019 г. Оперативная информация. Росстат. [Электронный ресурc] URL: http://www.gks.ru

\section{References}

1. Arkhangelskiy V.N. Faktory rozhdaemosti [Birth rate factors]. Moscow: TEIS, 2006. 399 p. (in Russian).

2. Demograficheskii ezhegodnik Rossii. 2002. Stat. sbornik. Rosstat [Demographic annual book of Russia. 2002. Statistical book. Federal Service of State Statistics]. Moscow, 2003. Available at: Http://www.gks.ru

3. Demograficheskii ezhegodnik Rossii. 2006. Stat. sbornik. Rosstat [Demographic annual book of Russia. 2006. Statistical book. Federal Service of State Statistics]. Moscow, 2007. Available at: Http://www.gks.ru

4. Demograficheskii ezhegodnik Rossii. 2010. Stat. sbornik. Rosstat [Demographic annual book of Russia. 2010. Statistical book. Federal Service of State Statistics]. Moscow, 2011. Available at: Http://www.gks.ru

5. Demograficheskii ezhegodnik Rossii. 2015. Stat. sbornik. Rosstat [Demographic annual book of Russia. 2015. Statistical book. Federal Service of State Statistics]. Moscow, 2016. Available at: Http://www.gks.ru

6. Demograficheskii ezhegodnik Rossii. 2019. Stat. sbornik. Prilozheniia. Rosstat [Demographic annual book of Russia. 2019. Statistical book. Applications. Federal Service of State Statistics]. Moscow, 2020. Available at: Http://www.gks.ru

7. Demograficheskii faktor $v$ sotsialno-ekonomicheskom razvitii regiona (na primere Permskoi oblasti). Pod. red. V.A. Iontseva [Demographic factor in the socioeconomic development of the region (on the example of the Perm Region). Under the editorship of V.A. Iontseva]. Moscow: TEIS, 2004. 256 p. (in Russian).

8. Demoskop. Demograficheskii elektronnyi zhurnal. Prilozheniia [Demoscop. Demographic electronic journal. Applications]. Available at: http://demoscope.ru/weekly/pril.php

9. Edinaia mezhvedomstvennaia informatsionno-statisticheskaia Sistema [Unified Interdepartmental Information and Statistical System]. Available at: https://fedstat.ru/indicator/36727 
10. Itogi mikroperepisi naseleniia RF $2015 \mathrm{~g}$. Razdel V - rozhdaemost i reproduktivnye plany [Results of the 2015 micro-census of the population of the Russian Federation. Section V - birth-rate and reproductive plans].

11. Available at: URL http://www.gks.ru/free_doc/new_site/population/demo/microperepis/finish/micro-perepis.html

12. Rozhdaemost, smertnost, estestvennyi prirost naseleniia po subektam RF za 2019 g. Operativnaia informatsiia. Rosstat [Birth rate, mortality, natural population growth in the constituent entities of the Russian Federation for 2019. Latest information. Federal Service of State Statistics]. Available at: http://www.gks.ru 